\title{
KEANEKARAGAMAN KANTONG SEMAR (Nepenthes spp) DI PULAU BATAM
}

\section{DIVERSITY OF PITCHER PLANT (Nepenthes spp) IN BATAM ISLAND}

\author{
Fauziah Syamsi ${ }^{1}$, Destaria Sudirman ${ }^{2}$ \\ ${ }^{1}$ Program Studi Pendidikan Biologi, Fakultas Keguruan dan Ilmu Pendidikan, \\ Universitas Riau Kepulauan, Indonesia \\ ${ }^{2}$ Program Studi Pendidikan Biologi, Fakultas Keguruan dan Ilmu Pendidikan, \\ STKIP Ahlussunnah, Indonesia

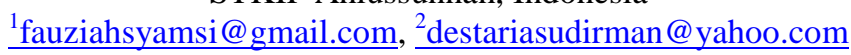

\begin{abstract}
Abstrak
Penelitian ini bertujuan untuk mengetahui keanekaragaman Nepenthes di pulau Batam. Penelitian dilakukan pada bulan April - Juni 2017 di empat hutan lindung di pulau Batam, yaitu Hutan lindung Bukit Dangas, Hutan Lindung Sei Ladi, Hutan Lindung Sei Harapan dan Hutan Lindung Duriangkang. Metode yang digunakan adalah survey dengan teknik purposive sampling, yaitu dengan menggunakan metode kuadrat. Dari penelitian yang telah dilakukan, ditemukan lima jenis Nepenthes, yaitu N. ampullaria, N. gracilis, N. rafflesiana, N. $x$ hookeriana, $\mathrm{N}$. x trichocarpa dimana dua jenis diantaranya adalah spesies hasil persilangan alami di alam. Jumlah individu terbanyak adalah N. gracilis yaitu sekitar $86 \%$ dari total individu Nepenthes yang ditemukan. kerapatan relatif tertinggi adalah N. gracilis di Hutan Lindung Sei. Ladi yaitu sebesar 97,89\%. Frekuensi relatif tertinggi adalah N. gracilis di Hutan Lindung Duriangkang yaitu sebesar 92\%. Indeks Nilai Penting tertinggi adalah N. gracilis di Hutan Lindung Duriangkang yaitu sebesar 188,67\%. Secara keseluruhan indeks keanekaragaman pada setiap lokasi pengamatan tergolong rendah yaitu $\left(0.15 \leq \mathrm{H}^{\prime} \leq 0.94\right)<1$. Indeks Kemerataan spesies tertinggi adalah di Hutan Lindung Sei. Ladi dengan nilai indeks Kemerataan sebesar 0.58 dengan kategori komunitas labil, sementara tiga lokasi lainnya tergolong komunitas tertekan dengan nilai indeks Kemerataan spesies $<0.5$.
\end{abstract}

Kata Kunci: Nepenthes, Keanekaragaman, Hutan lindung, Pulau Batam

\begin{abstract}
This study aims to determine the diversity of Nepenthes in Batam Island, The study was conducted from April to June 2017 in four protected forests. They are Bukit Dangas, Sei. Ladi, Sei Harapan and Duriangkang. The method for this research was purposive sampling that using quadratic method. From this research, it was found five species of Nepenthes, they are N. ampullaria, N. gracilis, N. rafflesiana, N. x hookeriana and N. $x$ trichocarpa. Two of them come from natural crosses in nature. The largest number of individuals was $N$. gracilis, about $86 \%$ of the total individual. The highest relative density is $N$. gracilis in Sei Ladi Protected forest about $97.89 \%$. The highest relative frequency is $N$. gracilis in Duriangkang protected forest about $92 \%$. The High Value Index is N. gracilis in Duriangkang protected forest which is $188.67 \%$. Diversity index for each observation site is low $\left(0.15 \leq H^{\prime} \leq 0.94\right)<1$. The highest evenness index is Sei. Ladi protected forest about 0.58 with the category of labile communities, where the other location are classified as depressed community with the evenness index 0.5 .
\end{abstract}

Keywords: Nepenthes, Diversity, Protected Forest, Batam Island 
Fauziah Syamsi dan Destaria Sudirman: Keanekaragaman Kantong Semar...

\section{PENDAHULUAN}

Pulau Batam adalah salah satu pulau yang berada di provinsi Kepulauan Riau. Pulau Batam memiliki luas $415 \mathrm{~km}^{2}$ dan terletak di sebelah selatan Laut Cina Selatan dan berbatasan dengan Riau, Singapura, Malaysia, Sumatera Selatan, Jambi dan Kalimantan Barat. Batam merupakan kota industri dengan pertumbuhan ekonomi yang sangat cepat. Pertumbuhan ekonomi ini berbanding lurus dengan pertambahan jumlah penduduk dan pembangunan infrastruktur di kota Batam. Hal ini memberikan dampak terhadap berkurangnya luas hutan konservasi di Batam sesuai dengan surat keputusan (SK) Menteri Kehutanan (Menhut) Nomor 867/Menhut-II/2014 tentang Kawasan Hutan Provinsi Kepulauan Riau bahwa hutan konservasi pulau Batam telah menurun drastis, seperti Taman Wisata Alam Muka Kuning Batam yang dulunya memiliki luas 2.065,65 hektar sekarang hanya tersisa 901 hektar. Pengurangan luas hutan konservasi di pulau Batam diduga akan terus terjadi karena minimnya informasi tentang potensi hutan konservasi tersebut sehingga para pembuat kebijakan tidak terlalu mempertimbangkan isu konservasi kawasan dalam alih fungsi hutan untuk berbagai keperluan. Sebagian besar hutan konservasi di pulau Batam juga berfungsi sebagai daerah resapan air bagi waduk-waduk yang dibuat untuk menyuplai air bersih bagi warga kota Batam. Dengan demikian, selain untuk melindungi keanekaragaman hayati, hutan konservasi di pulau batam juga memiliki peranan yang sangat penting bagi ketersediaan air bersih bagi warga Batam.

Salah satu potensi yang menonjol yang ditemukan di hutan konservasi pulau Batam adalah kantong semar (Nepenthes spp) yang dapat dijumpai hampir di seluruh kawasan dan sangat melimpah pada beberapa kawasan. Nepenthes spp. merupakan tanaman unik yang banyak tumbuh di hutan (Azwar et al., 2006). Penelitian terdahulu yang dilakukan oleh Syamsi dkk (2013) di Taman Wisata Alam Muka Kuning Batam, dengan wilayah sampling yang cukup kecil menemukan 4 spesies yaitu $N$. rafflesiana, $N$. gracilis, $N$. ampullaria dan $N$. hookeriana dengan ukuran populasi yang cukup besar. Diduga masih banyak spesies Nepenthes yang belum terdata karena minimnya penelitian yang dilakukan. .

Suburnya populasi Nepenthes di pulau Batam disebabkan karena hutan yang terdapat di pulau Batam tergolong hutan dataran rendah yang merupakan habitat yang sangat baik bagi Nepenthes. Hernawati dan Akhriadi (2006) menyatakan bahwa hutan dataran rendah $(<1000$ 
mdpl) dan hutan pegunungan (>1000 mdpl) adalah habitat yang esensial bagi Nepenthes. Selain itu, jenis tanah yang pada umumnya didominasi oleh tanah liat yang miskin hara juga menunjang pertumbuhan kantong yang merupakan bagian penting dalam pemenuhan unsur hara bagi pertumbuhan Nepenthes. Mansyur (2000) menyatakan Nepenthes merupakan tumbuhan insektivora yang mampu mencerna serangga yang terjebak di dalam kantong pada ujung sulur daunnya, serangga yang terperangkap tersebut dihancurkan, kemudian dijadikan sebagai sumber nutrisi (protein dan nitrogen). Cairan dalam kantong tanaman Nepenthes mengandung berbagai enzim, antara lain protease (paling dominan) dan Nepenthesin yang berfungsi mencerna serangga. Cara hidup Nepenthes ini secara tidak langsung juga dapat mengurangi jumlah populasi serangga hama yang dapat merugikan manusia.

Berdasarkan keunikan bentuk dan cara hidup serta fungsinya, Nepenthes dapat dijadikan sebagai salah satu potensi yang dapat ditonjolkan dalam isu konservasi kawasan hutan di pulau Batam. Masih minimnya informasi tentang keanekaragaman Nepenthes, maka penelitian tentang Keanekaragaman Jenis Nepenthes di pulau Batam perlu dilakukan.

Penelitian bertujuan untuk mengetahui keanekaragaman Nepenthes di pulau Batam dan membagikan informasi tentang potensi kawasan hutan di pulau Batam ke pihak terkait supaya dapat menjadi bahan pertimbangan dalam menetapkan kebijakan.

\section{METODOLOGI}

Penelitian ini dilaksanakan pada bulan April - Juli 2017 di hutan lindung yang terdapat di pulau Batam, yaitu Hutan lindung Bukit Dangas, Hutan Lindung Sei Ladi, Hutan Lindung Sei Harapan dan Hutan Lindung Duriangkang. Metode yang digunakan adalah survey dengan teknik purposive sampling, yaitu dengan menggunakan metode kuadrat untuk mengetahui keberadaan spesies di dalam suatu komunitas, metode ini merupakan suatu teknik analisis vegetasi dengan menggunakan petak contoh dengan prosedur sebagai berikut:

1. Penentuan daerah sampling, yang diawali dengan survey di empat hutan lindung yang telah ditetapkan untuk mendapatkan informasi awal tentang keberadaan Nepenthes di hutan tersebut. 
Fauziah Syamsi dan Destaria Sudirman: Keanekaragaman Kantong Semar...

2. Menentukan Jalur atau transek kemudian dibuat petak contoh dengan ukuran $5 \mathrm{~m} \mathrm{x} 5 \mathrm{~m}$ di sepanjang jalur dan pembuatan petak contoh dihentikan jika tidak ditemukan lagi Nepenthes di dalam petak contoh.

3. Melakukan pencatatan jenis dan jumlah individu setiap Nepenthes yang ditemukan pada masing-masing petak contoh.

Data yang diperoleh dianalisis dengan menghitung parameter-parameter sebagai berikut:

a. Dominansi jenis

Indeks Nilai Penting (INP) digunakan untuk menetapkan dominansi suatu jenis terhadap jenis lainnya. INP merupakan penjumlahan dari Kerapatan Relatif (KR) dan Frekuensi Relatif (FR) yang dapat diketahui dengan persamaan (Indriyanto, 2006) :

$\operatorname{Kerapatan}(\mathrm{K})=\quad \sum$ individu suatu jenis

Luas seluruh petak contoh

Kerapatan Relatif $(\mathrm{KR})=\quad \mathrm{K}$ suatu jenis $\quad \mathrm{x} 100 \%$

$\mathrm{K}$ total seluruh jenis

Frekuensi $(\mathrm{F})=\sum$ petak contoh ditemukan suatu jenis

$$
\sum \text { petak contoh }
$$

Frekuensi Relatif $(\mathrm{FR})=\underset{\mathrm{F} \text { total seluruh jenis }}{\mathrm{F} \text { suatu jenis }} \mathrm{x} 100 \%$

$\mathrm{INP}=\mathrm{KR}+\mathrm{FR}$

b. Indeks keanekaragaman (Diversitas)

Indeks keanekaragaman Shannon Wienner dihitung dengan menggunakan rumus berikut (Booth et al., 2003):

$\left.\mathrm{H}^{\prime}=-\Sigma[P i \ln P i)\right]$

Keterangan:

$\mathrm{H}^{\prime}=$ Indeks Shannon Wienner

$\mathrm{Pi}=(\mathrm{ni} / \mathrm{N})$

ni $=$ Jumlah individu spesies

$\mathrm{N}=$ Jumlah total untuk semua individu

c. Indeks Kemerataan (Index of Evenness)

Indeks kemerataan berfungsi untuk mengetahui kemerataan setiap jenis dalam setiap komunitas, dihitung dengan menggunakan rumus:

$\mathrm{E}=\mathrm{H}^{\prime} / \ln \mathrm{S}$ 
Keterangan:

$\mathrm{E}$ : Indeks kemerataan

H' : Indeks keanekaragaman Shannon-Wiener

Ln : Logaritma natural

S : Jumlah Jenis

Kriteria penilaian Indeks Kemerataan:

$0,00<\mathrm{E}<0,50$ komunitas tertekan

$0,50<\mathrm{E}<0,75$ komunitas labil

$0,75<\mathrm{E}<1,00$ komunitas stabil

\section{PEMBAHASAN}

Ditemukan lima jenis Nepenthes di pulau Batam. Terdapat penambahan jumlah jenis dari penelitian Syamsi (2013), yaitu sebanyak satu jenis. Adapun jenis-jenis Nepenthes dan jumlah individu masing-masing jenis dapat dilihat pada Tabel 1 berikut.

Tabel 1. Jenis dan Jumlah Individu Nepenthes di Pulau Batam

\begin{tabular}{rlcl}
\hline No & \multicolumn{1}{c}{ Spesies } & Jumlah Individu & Lokasi Ditemukan \\
\hline 1 & Nepenthes ampullaria & 75 & A, B, C \\
2 & Nepenthes gracilis & 1044 & A, B, C, D \\
3 & Nepenthes rafflesiana & 90 & A, B, C, D \\
4 & Nepenthes $x$ hookeriana & 4 & A, C \\
5 & Nepenthes $x$ trichocarpa & 5 & A, C \\
\hline \multicolumn{4}{c}{ Total } \\
\hline
\end{tabular}

Keterangan: $A=$ Hutan Lindung Bukit Dangas; $B=$ Hutan Lindung Sei Harapan; $C=$ Hutan Lindung Sei Ladi; $\mathrm{D}=$ Hutan Lindung Duriangkang.

Pada Tabel 1 di atas dapat dilihat bahwa Nepenthes yang dijumpai di semua lokasi penelitian adalah Nepenthes gracilis dan Nepenthes rafflesiana, dimana jumlah individu yang paling banyak dan sangat umum dijumpai adalah Nepenthes gracilis, yaitu sebanyak 1044. Banyaknya jumlah individu $N$. gracilis yang dijumpai di lokasi penelitian menandakan bahwa jenis ini merupakan spesies yang memiliki toleransi yang tinggi terhadap kondisi habitat sehingga dapat ditemukan di seluruh lokasi penelitian dengan jumlah individu yang relatif banyak. Hal yang sama juga ditemukan oleh Adam et al., (2009) yang dilakukan di Padang Tujuh Taman Negeri Endau- Rompin, Pahang- Malaysia, juga menemukan populasi $N$. 
gracillis yang paling dominan dibandingkan dengan jenis lainnya. Hal ini disebabkan oleh $N$. gracillis mempunyai daya adaptasi yang lebih tinggi dibandingkan dengan Nepenthes lainnya sehingga jenis ini banyak ditemukan diberbagai tempat. Puspitaningtyas et al., (2007) dan Azwar et al., (2006) menambahkan N. gracillis mampu hidup diberbagai tipe habitat dan jenis tanah, dengan kemampuan adaptasi yang tinggi.

\section{Deskripsi Jenis Nepenthes di Pulau Batam}

\section{Nepenthes ampullaria}

Nepenthes ampullaria memiliki bentuk batang bulat serta bentuk daun berupa sudip hingga lanset. Kantong bawah berbentuk tempayan dan berwarna hijau muda, merah, hijau lurik, merah tua sampai coklat. Kantong bawah biasanya ditemukan dalam jumlah yang sangat banyak sementara kantong atas sangat jarang ditemukan. Hal ini senada dengan yang dikemukakan oleh Setiawan (2013) bahwa kantong atas $N$. ampullaria sangat langka dan susah ditemukan. Kantong atas N. ampullaria berbentuk seperti corong.
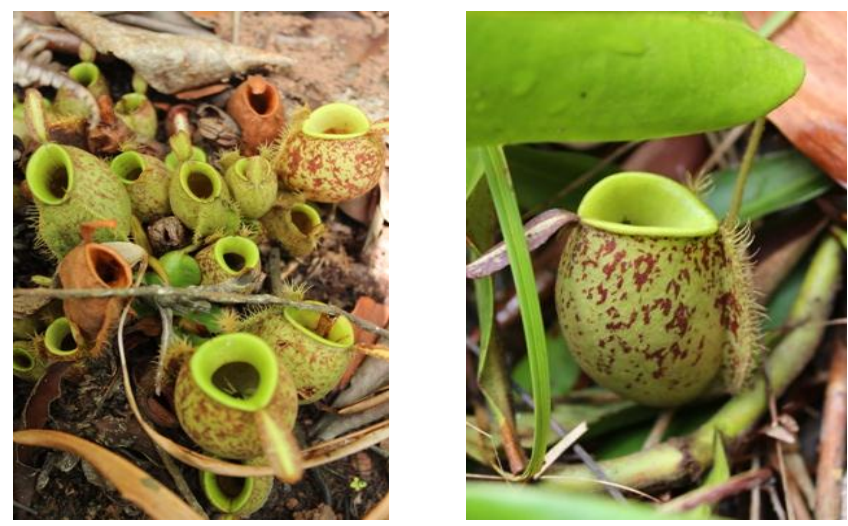

Gambar 1. N. ampullaria, Kantong roset (kiri), Kantong bawah (kanan)

\section{Nepenthes gracilis}

Nepenthes gracilis memiliki bentuk batang segitiga, daun berbentuk lanset, tipis sampai agak tebal. Kantong spesies ini berbentuk silindris dan memiliki. Bunga berbentuk tandan dengan warna coklat muda sampai coklat tua. 


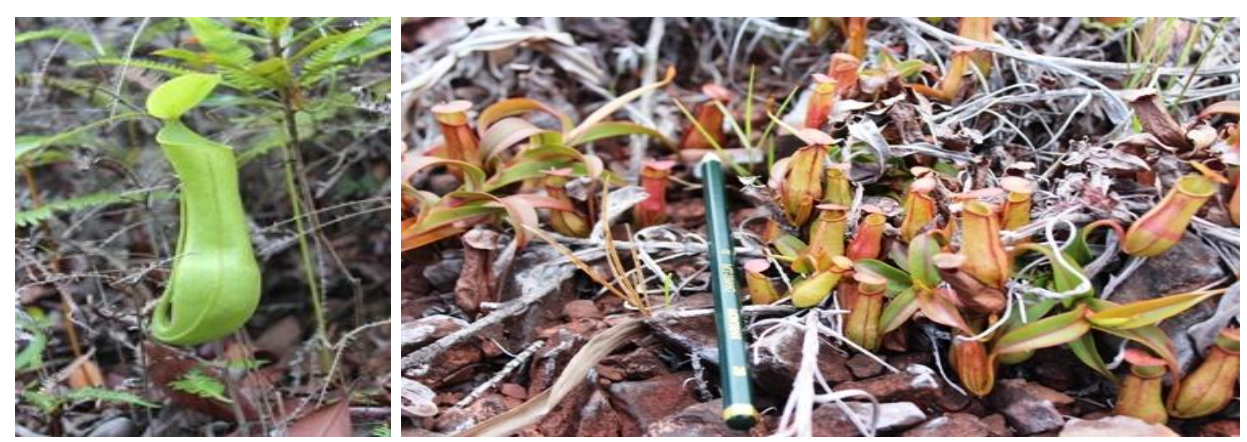

\section{Nepenthes rafflesiana}

Gambar 2. Nepenthes gracilis

Pada $N$. rafflesiana sangat umum dijumpai kantong atas dan kantong bawah secara bersamaan. Kantong atas berbentuk terompet dengan bibir tebal dan tidak mempunyai sayap. Sedangkan kantong bawah cenderung membulat dan memiliki sayap.
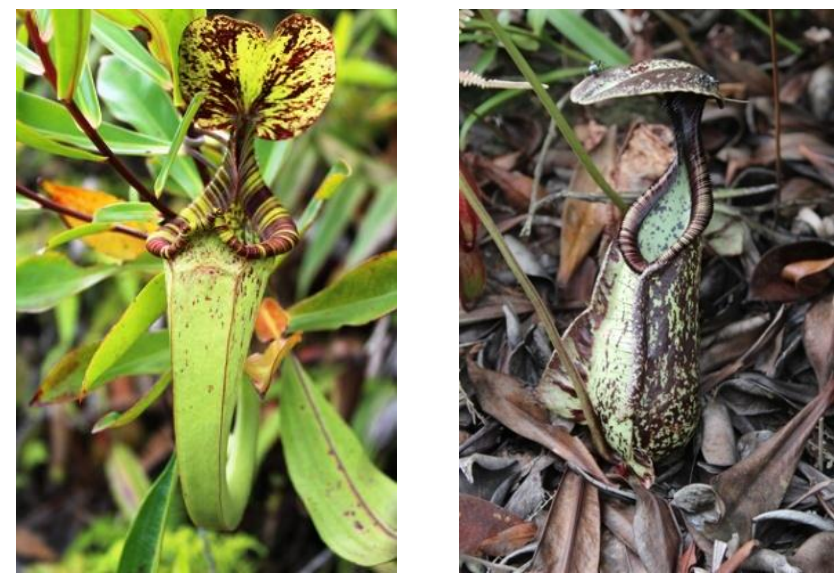

Gambar 3. Nepenthes rafflesiana, kantong bawah (kiri), kantong atas (kanan)

\section{Nepenthes $x$ hookeriana}

N. $x$ hookeriana adalah hasil persilangan secara alami yang terjadi $N$. ampullaria dengan $N$. rafflesiana. Dengan demikian bentuknya merupakan perpaduan dari bentuk kedua induk. Bentuk kantong menyerupai kantong $N$. rafflesiana, sedangkan bibir berbentuk bibir N. ampullaria. 

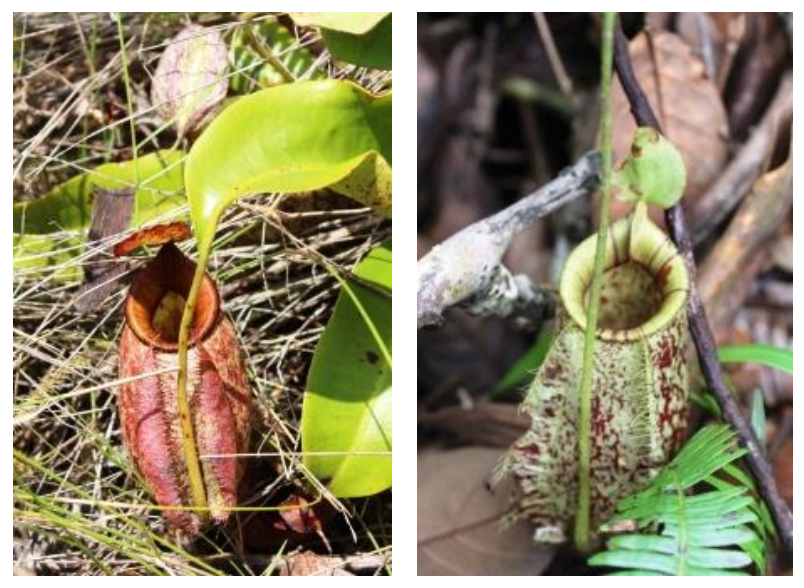

Gambar 4. Nepenthes $x$ hookeriana

\section{Nepenthes $x$ trichocarpa}

N. $x$ trichocarpa juga merupakan hasil persilangan alami dari induk $N$. ampullaria dengan $N$. gracilis. Dengan demikian ciri-ciri $N$. $x$ trichocarpa merupakan perpaduan dari kedua induk.
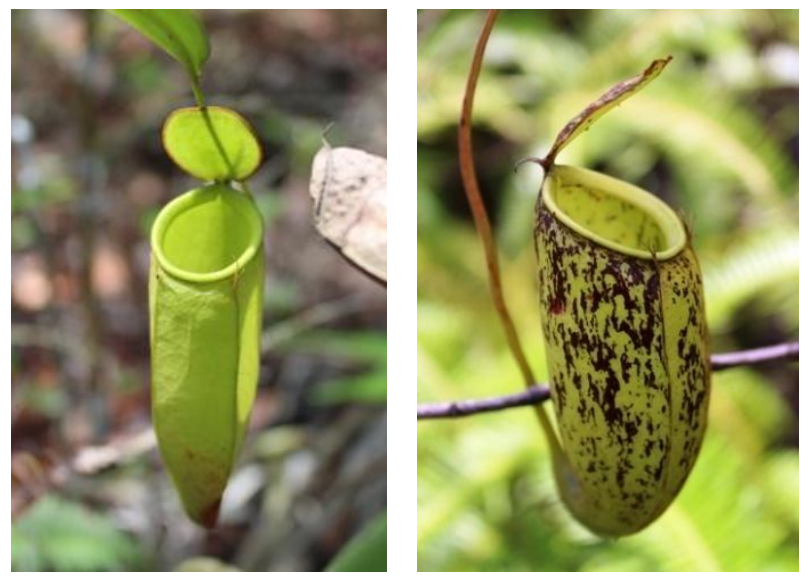

Gambar 5. Nepenthes x trichocarpa

Kantong relatif pendek jika dibandingkan $N$. gracilis dan bibir relative tipis jika dibandingkan bibir $N$. ampullaria. Wawna kantong bervariasi mulai dari hijau muda sampai hijau bercak merah kehitaman 


\section{Dominansi jenis Nepenthes di Pulau Batam}

Tabel. 2. Dominansi jenis di Pulau Batam

\begin{tabular}{|c|c|c|c|c|c|c|c|}
\hline Lokasi & No & Spesies & K & $\mathrm{KR}(\%)$ & $\mathrm{F}$ & FR $(\%)$ & INP $(\%)$ \\
\hline \multirow{6}{*}{ A } & 1 & N. ampullaria & 680 & 5.33 & 0.05 & 3.77 & 9.10 \\
\hline & 2 & N. gracilis & 11360 & 89.03 & 0.90 & 67.92 & 156.95 \\
\hline & 3 & N. rafflesiana & 520 & 4.08 & 0.10 & 7.55 & 11.62 \\
\hline & 4 & N. $x$ hookeriana & 80 & 0.63 & 0.03 & 1.89 & 2.51 \\
\hline & 5 & N. $x$ trichocarpa & 120 & 0.94 & 0.25 & 18.87 & 19.81 \\
\hline & Total & & 12760 & 100 & 1.33 & 100 & 200 \\
\hline \multirow{4}{*}{ B } & 1 & N. ampullaria & 40 & 0.30 & 0.03 & 2.50 & 2.80 \\
\hline & 2 & N. gracilis & 13000 & 97.89 & 0.88 & 87.50 & 185.39 \\
\hline & 3 & N. rafflesiana & 240 & 1.81 & 0.10 & 10.00 & 11.81 \\
\hline & Total & & 13280 & 100 & 1.00 & 100 & 200 \\
\hline \multirow{6}{*}{$\mathrm{C}$} & 1 & N. ampullaria & 2280 & 15.97 & 0.30 & 17.39 & 33.36 \\
\hline & 2 & N. gracilis & 9280 & 64.99 & 0.88 & 50.72 & 115.71 \\
\hline & 3 & N. rafflesiana & 2560 & 17.93 & 0.50 & 28.99 & 46.91 \\
\hline & 4 & N. $x$ hookeriana & 80 & 0.56 & 0.03 & 1.45 & 2.01 \\
\hline & 5 & N. $x$ trichocarpa & 80 & 0.56 & 0.03 & 1.45 & 2.01 \\
\hline & Total & & 14280 & 100 & 1.73 & 100 & 200 \\
\hline \multirow{3}{*}{$\mathrm{D}$} & 1 & N. gracilis & 8120 & 96.67 & 0.58 & 92.00 & 188.67 \\
\hline & 2 & N. rafflesiana & 280 & 3.33 & 0.05 & 8.00 & 11.33 \\
\hline & Total & & 8400 & 100 & 0.63 & 100 & 200 \\
\hline
\end{tabular}

Keterangan: A= Hutan Lindung Bukit Dangas; $B=$ Hutan Lindung Sei. Harapan; $C=$ Hutan Lindung Sei. Ladi; $\mathrm{D}=$ Hutan Lindung Duriangkang; $\mathrm{K}=$ Kerapatan (ind/Ha); KR= Kerapatan Relatif (\%); $\quad \mathrm{F}=$ Frekuensi; FR = Frekuensi Relatif (\%); INP= Indeks Nilai Penting (\%).

Pada Tabel 2 di atas dapat dilihat bahwa kerapatan relatif tertinggi untuk semua lokasi penelitian adalah $N$. gracilis dengan nilai secara berturut-turut 89,03\%, 97,89\%, 64,99\% dan 96,67\%. Hal yang sama juga ditemukan oleh Khairil (2015) bahwa kerapatan relatif tertinggi adalah $N$. gracilis dengan nilai $\mathrm{KR} 85,71 \%$ dan $75,30 \%$. Frekuensi relatif tertinggi di semua lokasi penelitian adalah $N$. gracilis dengan nilai secara berturut-turut 67,92\%, 87,50\%, $50,72 \%$ dan 92\%. Indeks Nilai Penting tertinggi untuk semua lokasi penelitian juga $N$. gracilis dengan nilai secara berturut-turut 156,95\%, 185,39\%, 115,71\% dan 188,67\%. Hasil penelitian menunjukan bahwa $N$. gracilis terdapat dalam jumlah yang besar dan mampu hadir pada setiap petak pengamatan dibandingkan jenis kantong semar lainnya, dengan demikian $N$. gracilis bisa dikatakan jenis dominan di pulau Batam. Odum (1993) menjelaskan bahwa 
Fauziah Syamsi dan Destaria Sudirman: Keanekaragaman Kantong Semar...

suatu jenis dapat dikatakan dominan apabila jenis yang bersangkutan terdapat dalam jumlah yang besar, tersebar merata pada suatu daerah.

\section{Indeks Keanekaragaman dan Kemerataan Nepenthes di Pulau Batam}

Tabel. 3. Indeks diversitas Shanon Wiener (H') dan Indeks Kemerataan $(E)$

\begin{tabular}{ccccc}
\hline Lokasi & Spesies & Individu & $\begin{array}{c}\text { Indeks Diversitas } \\
\left(\mathbf{H}^{\prime}\right)\end{array}$ & $\begin{array}{c}\text { Indeks Kemerataan } \\
(\mathbf{E})\end{array}$ \\
\hline A & 5 & 319 & 0.47 & 0.29 \\
B & 3 & 332 & 0.11 & 0.10 \\
C & 5 & 357 & 0.94 & 0.58 \\
D & 2 & 210 & 0.15 & 0.21 \\
\hline Pulau Batam & 5 & 1218 & 0.54 & 0.33 \\
\hline
\end{tabular}

Keterangan: $A=$ Hutan Lindung Bukit Dangas; $B=$ Hutan Lindung Sei. Harapan; $C=$ Hutan Lindung Sei. Ladi; $\mathrm{D}=$ Hutan Lindung Duriangkang.

Pada Tabel 3 diatas dapat dilihat bahwa secara keseluruhan indeks keanekaragaman (indeks diversitas) pada setiap lokasi pengamatan tergolong rendah yaitu $\left(0.15 \leq \mathrm{H}^{\prime} \leq 0.94\right)<1$. Hal yang sama juga terdapat semua lokasi penelitian (pulau Batam) dimana nilai indeks keanekaragam secara keseluruhan juga tergolong rendah, yaitu sebesar 0.54. Dari semua lokasi pengamatan, lokasi dengan indeks keanekaragaman tertinggi adalah pada Hutan Lindung Sei Ladi yaitu sebesar 0.94 dan tertinggi berikutnya adalah Hutan Lindung Bukit Dangas, yaitu sebesar 0.47. Sementara dua lokasi lainnya, Hutan Lindung Sei Harapan dan Hutan Lindung Duriangkang sangat rendah, yaitu secara berturut turut adalah 0.11 dan 0.15. Rendahnya nilai indeks keanekaragaman Nepenthes di lokasi penelitian menandakan bahwa popolasi Nepenthes di lokasi ini tergolong kurang stabil. Indeks Kemerataan spesies tertinggi adalah di Hutan Lindung Sei. Ladi dengan nilai indeks Kemerataan sebesar 0.58 dengan kategori komunitas labil, sementara tiga lokasi lainnya tergolong komunitas tertekan dengan nilai indeks Kemerataan spesies $<0.5$.

\section{KESIMPULAN DAN SARAN}

Berdasarkan penelitian yang telah dilakukan, diperoleh kesimpulan sebagai berikut:

1. Terdapat lima jenis Nepenthes di lokasi penelitian, yaitu N. ampularia, N. gracilis, N. rafflesiana, $N . x$ hookeriana, $N . x$ trichocarpa dimana dua jenis diantaranya adalah spesies hasil persilangan alami di alam, yaitu $N$. x hookeriana, $N$. x trichocarpa . 
2. Jumlah individu terbanyak adalah $N$. gracilis yaitu sekitar $86 \%$ dari total individu Nepenthes yang ditemukan.

3. Indeks Nilai Penting tertinggi untuk semua lokasi penelitian adalah N. gracilis di Hutan Lindung Duriangkang yaitu sebesar 188,67\%.

4. Indeks keanekaragaman dan Kemerataan tergolong rendah untuk semua lokasi pengamatan.

Berdasarkan kesimpulan diatas, dapat disarankan beberapa hal berikut:

1. Diharapkan pemerintah dapat membuat sebuah regulasi tertentu supaya spesies Nepenthes yang ada di Batam dapat terjaga dengan baik.

2. Dibutuhkan waktu dan lokasi sampling yang lebih luas untuk mendapatkan hasil yang maksimal.

\section{REFERENSI}

Adam, J.H., J. Nur Maisarah, A.T. S. Norhafizah, M.Y. Harun, H. Azman. 2009. Kepadatan dan Taburan Tiga Fasa Hidup Nepenthes di Padang Tujuh Taman Negeri EndauRompin, Pahang. In Adam, J.H, M.B. Gasim and Z. Sarkawi (eds.). Proceeding: Bio. Kejuruteraan dan Kelestarian ekosistem. Universiti Kebangsaan Malaysia. Malaysia.

Azwar, F, A. Kunarso, dan T. Rahman S. 2006. Kantong Semar (Nepenthes sp.) di Hutan Sumatera, Tanaman yang Unik Semakin Langka. Makalah Penunjang pada Ekspose Penelitian. Padang.

Hernawati \& Akhriadi. 2006. A File Guide to the Nepenthes of Sumatera. Pili Publisher. Bandung.

Khairil, M., I.Dewantara dan T. Widiastuti. 2015. Studi Keanekaragaman Jenis Kantong Semar (Nepenthes spp) di Kawasan Hutan Bukit Beluan Kecamatan Hulu Gurung. Jurnal Hutan Lestari (2015) Vol. 3 (2) : 259 - 264

Odum, E, P. 1993. Dasar-Dasar Ekologi. Terjemahan Tjahjono Samingan. Gadjah Mada University Press, Yogyakarta.

Puspitaningtyas, D. Murti dan H. Wawaningrum. 2007. Keanekaragaman Nepenthes di Suaka Alam Sulasih Talang-Sumatra Barat. Jurnal Biodiversitas. 8 (2): 152-156

Setiawan, H. 2013. Inventarisasi Nepenthes di Hutan Adat Kantuk dan Implementasinya berupa Buku Saku Keanekaragaman Hayati Indonesia. Artikel Penelitian. Program Studi Pendidikan Biologi, Jurusan Pendidikan Matematika Dan Ilmu Pengetahuan Alam, Fakultas keguruan dan ilmu pendidikan, Universitas Tanjungpura, Pontianak.

Syamsi, F., Ramses dan W.H. Saragih. 2013. Studi Perbandingan Keanekaragamn Jenis Kantong Semar (Nepenthes, spp) di Taman Wisata Alam Muka Kuning Batam. Jurnal Simbiosa Vol 3 Nov 2013. 
Fauziah Syamsi dan Destaria Sudirman: Keanekaragaman Kantong Semar... 